Marketing in Asia Group

\title{
Antecedents of Organizational Citizenship Behavior and the Mediating Effect of Organization Commitment in the Hotel Industry
}

\author{
Jue Xin Tan \\ Department of International Business Administration, International College, Tunghai \\ University, Taiwan \\ Tat Huei Cham \\ Department of International Business, Universiti Tunku Abdul Rahman, Selangor, Malaysia \\ Dahlia Zawawi \\ Department of Management and Marketing, Universiti Putra Malaysia, Selangor, Malaysia \\ Yuhanis Abdul Aziz \\ Department of Management and Marketing, Universiti Putra Malaysia, Selangor, Malaysia
}

\begin{abstract}
The rapid growth of the hotel industry in the current era of globalization requires hotel operators to acknowledge the importance of service provision and its management in order to compete effectively and to gain competitive advantage at the same time. Building a strong workforce is essential to realize this vision. Therefore, it is vital for the hotel operators to establish a good relationship between their management and the employees to achieve its goals and objectives. As such, this paper aims to examine the importance of emotional intelligence in shaping benevolent leaders and organizational commitment as the mediator of the relationship between benevolent leadership and organizational citizenship behavior. This study is one of the pioneer studies of benevolent leadership conducted in a multicultural context. Moreover, this study also highlighted the effectiveness of benevolent leadership in encouraging voluntary extrarole effort and improving the turnover issues in the hotel industry of Malaysia. The data was collected using multistage sampling from 300 hotel employees from fourand five-star hotels in Klang Valley of Malaysia. Both Statistical Package for the Social Sciences (SPSS) and AMOS (Analysis of Moment Structures) statistical software were used for the hypotheses testing. The results from the analysis showed that the emotional intelligence of supervisors is significantly related to benevolent leadership. Organizational commitment was found to have a mediation effect on the relationship between benevolent leadership and organizational citizenship behavior.
\end{abstract}

Keywords: Benevolent Leadership, Emotional Intelligence, Organizational Commitment, Organizational Citizenship Behavior, Hotel Industry

Publication Details: Received 15 Nov 2018; Revised 1 Aug 2019; Accepted 3 Aug 2019 


\section{Introduction}

As the hotel industry continues to grow across the world, the hotel operators are required to have reliable and organized management line-up in order to be competitive and relevant to the needs and wants of the customers. However, the hotel industry is greatly challenged with the longstanding turnover issue in both developed and developing countries (Abdullah, Alias, Zahari, Karim, Abdullah, Salleh, \& Musa, 2010; Sangaran \& Jeetesh, 2015). This is due to the issues such as long and irregular working hours, poor working conditions and low wages experienced by the employees of the hotels (Lo \& Lamm, 2005). In Malaysia for example, it was reported that half of the overall turnover rate in the tourism and hospitality industry emanated from the hotel industry (Saad, Yahya, \& Pangil, 2012). The latest statistics from the Ministry of Human Resource of Malaysia showed that by the end of the first quarter of 2017, there were as many as 1637 vacancies available in the accommodation and food services sector (Ministry of Human Resource Malaysia, 2017a). However, the figures skyrocketed to 5267 at the end of the third quarter in 2017 (Ministry of Human Resource Malaysia, 2017b). This scenario orchestrated that the hospitality industry is regarded as one of the industries that has a significant turnover rate in comparison to other industries.

In view of the shortcomings, scholars have expressed their concerns towards the employee turnover issues of the hotel industry in Malaysia (e.g. Sangaran \& Jeetesh, 2015; Albattat \& Som, 2013; Saad et al., 2012; Abdullah et al., 2010). As tourism industry plays a crucial role in being a major income generator and growth contributors to the Malaysian economy, the high turnover rate of hotel employees has become an encumbrance to the development of tourism industry (Abdullah et al., 2010; Mastura, Toh, \& Zaleha, 2011; Salman \& Hasim, 2012). A survey conducted by Kelly Services (2012) also revealed that the hospitality/travel/leisure sector has recorded the lowest level of employees' satisfaction towards management's leadership style compared to other industries. Hence, it is important for the organizations to have high-quality human resource management practices and benevolent leaders to minimize the turnover rate. The past studies claimed that the benevolent attributes among the leaders could be one of the key factors that could possibly improve the employee turnover situations and facilitate productive workforce (Farh, Cheng, Chou, \& Chu, 2006; Farh \& Cheng, 2000).

In addition, benevolent leadership approach has been widely acknowledged as the most desirable leadership style in services setting (Chan \& Mak, 2012). There are studies that suggested the relationship between leaders and employees and the treatment towards the employees can minimize the turnover issues in the hotel industry (e.g. Abdullah et al., 2010; Nankervis, Compton, \& Baird, 2008). By providing individualized concern for subordinates' personal and familial well-being, benevolent leaders may build a favorable leader-employee relationship and subsequently reduce the likelihood of employees leaving their job (Ayupp \& Kong, 2010). On the positive note, employees would have responded to the benevolent leaders by contributing more on their work in exchange due to the value they perceived from the relationship (Farh et al., 2006; Farh \& Cheng, 2000). 
Although benevolent leadership has been an area of interest in management studies, there were limited studies that emphasized the antecedent of benevolent leadership. As hotel industry is considered as a service industry that normally demands high emotional labor to satisfy customers (Cham \& Easvaralingam, 2012; Cheng, Shaheen, \& Cham, 2014), this study intends to add to the growing knowledge base by proposing emotional intelligence as the pre-requisite to benevolent leadership. Besides emotional intelligence, the present study also proposed the possible influence of benevolent leadership on the employees' organizational commitment. Granting the fact that organizational commitment has been widely examined as the positive outcome of various leadership styles (Ahmadi \& Avajian, 2011; Erben \& Güneşer, 2008), the empirical evidence that proposed the relatedness of benevolent leadership and organizational commitment in hospitality setting are still lacking to date.

In addition to above, organizational commitment has been extensively studied as the antecedent of organizational citizenship behavior (e.g. Ahmadi \& Avajian, 2011; Peterson \& Xing, 2007; Riketta \& Landerer, 2002; Podsakoff, MacKenzie, Paine, \& Bachrach, 2000; MacKenzie, Podsakoff, \& Ahearne, 1998; Organ \& Ryan, 1995). However, the study that addressed the relationship between organizational commitment and organizational citizenship behavior in the hospitality literature is still relatively scant. Since that the hotel industry in Malaysia has been reported to suffer from a high turnover rate (Saad et al., 2012), therefore, organizational citizenship behavior is viewed as an important element in the hospitality setting especially when it promotes loyalty behavior among the employees towards the firms, being proud of the company, and ultimately remain with the hotel that they worked with. Moreover, organizational citizenship behavior among staff is able to improve their performance by minimizing their errors, taking initiative to seek for better solution, promote collaboration and improving their level of quality of their service provision.

In view of the benefits of organizational citizenship behavior in enhancing employees' performance and promote organizational success, the finding from this study is expected to highlight the importance of leaders' benevolent behavior and their commitment in relation to their citizenship behavior. Moreover, the mediating role of organizational commitment has also been highlighted in the past studies (Caillier, 2015; Dhar, 2015; Yousef, 2017). To the best knowledge of the researchers, the review of the past literature indicates that the studies that examine the mediating effect of organizational commitment in the relationship between benevolent leadership and organizational citizenship behavior are virtually none. For example, it was found that organizational commitment mediated the relationship between servant leadership and organizational citizenship behavior (Behery, Al-Nasser, Jabeen \& Ei Rawas, 2018; Rosnani, 2018). Hence, this scenario suggested that there is a need for researchers to address this research gap.

Referring to the research deficiency identified above, the present study attempts to achieve the following objectives: (1) to examine the impact of emotional intelligence on benevolent leadership, (2) to examine the interrelationship between benevolent leadership, organizational commitment and organizational citizenship behavior, and (3) to examine the mediating effect of organizational commitment in the relationship between benevolent leadership and organizational citizenship behavior. The following section presents a review of constructs in the study and hypotheses development. 
Subsequently, the research methodology and results of data analysis are presented. Lastly, the findings and the implications of the study are discussed.

\section{Literature Review}

\section{Benevolent Leadership}

Since its inception, benevolent leadership has been widely studied in the Chinese context as it has been viewed as a leadership style that aligns with the Confucius teachings which advocates the vitality of the vertical relationship between superiors and subordinates (Wang \& Cheng, 2010; Niu, Wang, \& Cheng, 2009). Farh and Cheng (2000) initiated the wave of interest among Chinese scholars in examining benevolent leadership by proposing it as an individualized leadership style with holistic care for employees' personal well-being. In the western context, benevolent leadership can be explained as the process of forming a cycle of encouraging and initiating positive change in organizations through (1) ethical practices in decisionmaking process; (2) promoting positive actions; (3) making a sense of meaning; and (4) continuously creating a positive outcome for the community (Karakas \& Sarigollu, 2012).

According to Desrosiers and Thomson (2011), benevolent leaders can be described as individuals who are having goodwill, good intention, and take actions for the greater good for his or her subordinates. Benevolent leaders are the ones who master the leading skills and possess proficiency in supervising the followers. Wang and Cheng (2010) described that benevolent leaders provide individualized concern to their employees beyond the working context, for instances, allowing opportunities to correct mistakes, coaching and mentoring, avoiding public embarrassment of employees, treating their employees as family members, supporting employees during their personal crises, and showing holistic concern beyond professional relationships. The genuine and sincere concerns demonstrated by the benevolent leaders are able to improve productivity among the employees, as this will make the staff to view the reciprocation as an obligation (Farh \& Cheng, 2000; Farh et al., 2006). Wang and Cheng (2010) further argued that benevolent leadership implied that leaders have to fulfill mutual obligations in social relations.

In addition, benevolent leadership has been widely studied across the business and management context due to its positive impacts on the performance of the organization. For example, previous studies have found that there was significant effect of benevolent leadership on several positive organizational outcomes such as creativity in the workplace (Lin, Ma, Zhang, Li, \& Jiang, 2016; Wang \& Cheng, 2010), innovative behavior (Gumusluoglu, Karakitapoğlu-Aygün, \& Scandura, 2017), psychological well-being (Erkutlu \& Chafra, 2016), organizational performance (Li, Rubenstein, Lin, Wang, \& Chen, 2018; Chan, 2017; Karakas \& Sarigollu, 2012), follower task performance (Chan \& Mak, 2012), organizational commitment (Karakas \& Sarigollu, 2012), and organizational citizenship behavior (Ghosh, 2015; Chan \& Mak, 2012; Karakas \& Sarigollu, 2012). 


\section{Emotional Intelligence}

Emotional intelligence is defined as a subset of social intelligence that involves the ability to monitor one's own and others' feelings and emotions, to discriminate among them and to use this information to guide one's thinking and actions (Salovey \& Mayer, 1990). Salovey and Mayer (1990) stated emotional intelligence as a type of social intelligence during the early stage of conceptualization. According to the theory of multiple intelligences, Gardner (1983) proposed that the intrapersonal and interpersonal intelligences allow one to recognize the emotions, distinguish between the emotions and utilize emotional information to handle the circumstances effectively. Gardner (1983) further argued that those with higher interpersonal intelligence are capable of communicating more effectively and empathizing others easily. Bar-On (2006) developed the model of emotional-social intelligence and explained that the cross-section of interrelated emotional and social competencies, skills and facilitators form the context of emotional-social intelligence. It was reported that intelligence aspect can strongly assists individuals to understand and express themselves, understand others and relate with them (Bar-On, 2006). Goleman (1995) has successfully made emotional intelligence more accessible by synthesising the correlations explored in the previous studies of emotional intelligence and proposed that the experience and expression of emotions are categorized as the domain of intelligence, which influences one's social and communication capabilities.

Emotional intelligence is an important element of the human skills especially when dealing with the job that requires substantial amount of human interaction, for example, the hotel industry (Lee \& Ok, 2012; Pressentin, 2015). It was reported that the occupations that demand high interpersonal intelligence include salesperson, politicians, managers, teachers, lecturers, counselors, and social workers (Gardner, 1983). Smollan and Parry (2011) argued that leaders with high emotional intelligence are capable of recognizing the emotions of followers even if the followers intentionally or subconsciously disguise their emotions. The previous studies have also suggested that a good leader should be consciously aware of self-emotion and emotion of others, and having the ability to perceive when to make improvement by adjusting their behavior (e.g. Bratton, Dodd, \& Brown, 2011; Wong \& Law, 2002).

In addition, emotional intelligence plays a critical role in determining the success of a leader in the workplace (Cook, 2006; Dabke, 2016). Scholars suggested that a good leader should possess a good emotion control and the ability to make improvement, and should be able to adapt their behaviors to the improvement (Bratton et al., 2011; Wong \& Law, 2002). According to Pressentin's (2015) study in the hotel industry, a leader should possess emotional intelligence by practicing effective communication, adaptability and coaching skills in order to achieve the organizational goals. Numerous studies have suggested that emotional intelligence has a significant impact on leadership approach (e.g. Bratton et al., 2011; Dabke, 2016; Hong, Catano, \& Liao, 2011; Lindebaum \& Cartwright, 2011; McEnrue, Groves, \& Shen, 2009; Stein, Papadogiannis, Yip, \& Sitarenios, 2009; Yunus \& Anuar, 2012; Polychroniou, 2009). For example, the study by Hong et al. (2011) found that emotional intelligence has a significant impact on leaders' motivation to lead. Moreover, Yunus and Anuar (2012) reported in their study that there is a positive association between emotional intelligence and transformational leadership. Erkutlu and Chafra (2016) proposed emotional intelligence as an essential skill for benevolent leaders to identify 
employees' personal needs. Based on the evidence above, it can be inferred that emotional intelligence has a positive influence on benevolent leadership. Hence, the following hypothesis was developed:

H1 Emotional intelligence has a positive direct effect on benevolent leadership.

\section{Organizational Commitment}

Organizational commitment is defined as a psychological state that describes an employee's relationship with the organization and reduces the likelihood that he/she will leave it (Allen \& Meyer, 1990; Allen \& Meyer, 2000). Organizational commitment has been a major area of interest for researchers and it is conceptually characterized by the employees' (1) strong desire to uphold their membership in the organization, (2) strong belief in organizational goals and values, and (3) willingness to exert considerable effort on behalf of the organization that they are attached with (Mowday et al., 1979). Alternatively, Allen and Meyer (1990) proposed that there are three components that constitute organizational commitment, namely, affective commitment (a desire), normative commitment (an obligation) and continuance commitment (a need), to retain employees in an organization. According to Ahuja, Padhy and Srivastava (2018), individual variables (e.g. age, tenure, gender, education, employment alternatives, sense of competence and locus of control) and organizational variables (e.g. perceived structure, process, and climate, job satisfaction, organizational culture, organizational socialization, person-organization fit and role conflict) play a critical role in shaping commitment among the employees.

Organizational commitment is also known to have an influence on organizational behavior especially in enhancing employees' motivation, performance, morale, and organizational success (Meyer \& Schoorman, 1998). Bateman and Strasser (1984) stated that organizational commitment demonstrates the loyalty of the employees and their desire to maintain membership in the organization. As such, organizational commitment is commonly used as the indicator of employees' turnover (Allen \& Meyer, 1990). The past studies also revealed that organizational commitment has been found to be the precedent of various leadership styles such as charismatic leadership (Rowden, 2000), ethical leadership (Neubert, Wu, \& Roberts, 2013), transformational leadership (Othman, Abdullahi Mohammed, \& Lawrence D'Silva, 2013), active and passive leadership styles (Sušanj \& Jakopec, 2012), leadership practices (Al-sharafi \& Rajiani, 2013) and leadership behavior (Tatlah, Ali, \& Saeed, 2011).

In addition, the past studies reported that benevolent leaders who showed concern for employees' well-being were able to create commitment among their subordinates (Chan \& Mak, 2012; Chen et al., 2018; Peterson \& Xing; 2007; Wang \& Cheng, 2010). For example, Peterson and Xing (2007) in their study of 345 respondents from private, mixed economy, and government-owned organizations in northeastern China suggested that favorable leadership behaviors would contribute to higher levels of commitment among staff workers. Hence, the evidence from the literature revealed that organizational commitment is expected to have an impact on benevolent leadership. As such, the following hypothesis was developed: 
H2 Benevolent leadership has a positive direct effect on organizational commitment.

\section{Organizational Citizenship Behavior}

Organizational citizenship behavior refers to a series of voluntary behavior of employees that are not formally expected by the company (Organ, 1990; Bateman \& Organ, 1983). The concept of organizational citizenship behavior was first proposed by Organ (1990) and was conceptualized based on sportsmanship, altruism, courtesy, conscientiousness and civic virtue. Subsequent to the study by Organ (1990), many studies conceptualized organizational citizenship behavior differently based on the context of the studies (e.g. Moorman \& Blakely, 1995; Podsakoff \& Mackenzie, 1997; Podsakoff et al., 2000). For example, the most popular study by Podsakoff and Mackenzie (1997) conceptualized organizational citizenship behavior in the context of helping behavior, sportsmanship, organizational loyalty, organizational compliance, individual initiative, civic virtue, and self-development.

Previous studies have consistently claimed that organizational citizenship behavior is effective in making organization successful and improving its performance (e.g. Chu \& Hung, 2009; Chen, Eberly, Chiang, Farh, \& Cheng, 2011; Podsakoff et al., 2000). Particularly, organizational citizenship behavior among the employees was argued to be greatly influenced by benevolent leadership (e.g. Chan \& Mak, 2012, Karakas \& Sarigollu, 2012). This scenario is particularly true, as benevolent leaders will provide individualized concern and support to their subordinates in whom they return the kindness by performing extra-role tasks that are beneficial to the organization (Chan \& Mak, 2012). The findings are consistent with the past studies that reported that organizational citizenship behavior is the most prevalent organizational outcomes of benevolent leadership (e.g Ghosh, 2015; Tang \& Naumann, 2015).

Evidently, organizational commitment has also been widely studied as the antecedent of organizational citizenship behavior (e.g. Ahmadi \& Avajian, 2011; Behery et al., 2018; Han et al., 2016; Kim, 2014; Peterson \& Xing, 2007). For example, the study by Han et al. (2016) on 600 employees from five large companies in South Korea found that the commitment of the employees greatly influenced their organizational citizenship behavior. It is also noticeable in the past studies that organizational commitment has a mediating effect in facilitating the influence of leadership towards organizational citizenship behavior. In particular, Rosnani (2018) found that there is an indirect influence between servant leadership and extra-role behaviors, mediated by affective commitment. Behery et al. (2018) revealed that followers' commitment mediates the negative relationship between toxic leadership and organizational citizenship behaviors. In addition, Li et al. (2018) in their study found that there is a relationship between benevolent leadership and team performance. Li et al.'s (2018) study also indicated that team performance is at the best when the staff are committed and there is a considerable amount of benevolent leadership experienced by them. This above evidence shows that benevolent leadership may have an indirect effect on organizational citizenship behavior via commitment as one of the components of organizational commitment, affective commitment, specifies that employees are emotionally attached to their organization and inclined to contribute more, resulting in efficacious performance. 
In view of the nature of the hotel industry which is a labor-intensive industry that largely depends on human resources to provide customized and extravagant quality services, improving employees' attitude and mentality could be the imperative solution to curb turnover issues. By practicing benevolent leadership among the management, it is able to stimulate employees' commitment and further cultivate the organizational citizenship behaviors among them. This would definitely encourage them to pay attention to the finer points in hotels' daily operations, serve the customers with the appropriate mind-set, and therefore enhancing the overall quality of the service. Based on the discussion above, this study hypothesized the following hypotheses:

H3 There is a positive relationship between benevolent leadership and organizational citizenship behavior.

H4 There is a positive relationship between organizational commitment and organizational citizenship behavior.

H5 There is a mediating effect of organizational commitment on the relationship between benevolent leadership and organizational citizenship behavior.

Figure 1 shows the conceptual framework of this study. This study intends to examine how emotional intelligence encourages the emergence of the leaders' benevolent behavior, and how this leadership style further enhances employees' citizenship behavior with employees' commitment as a mediator.

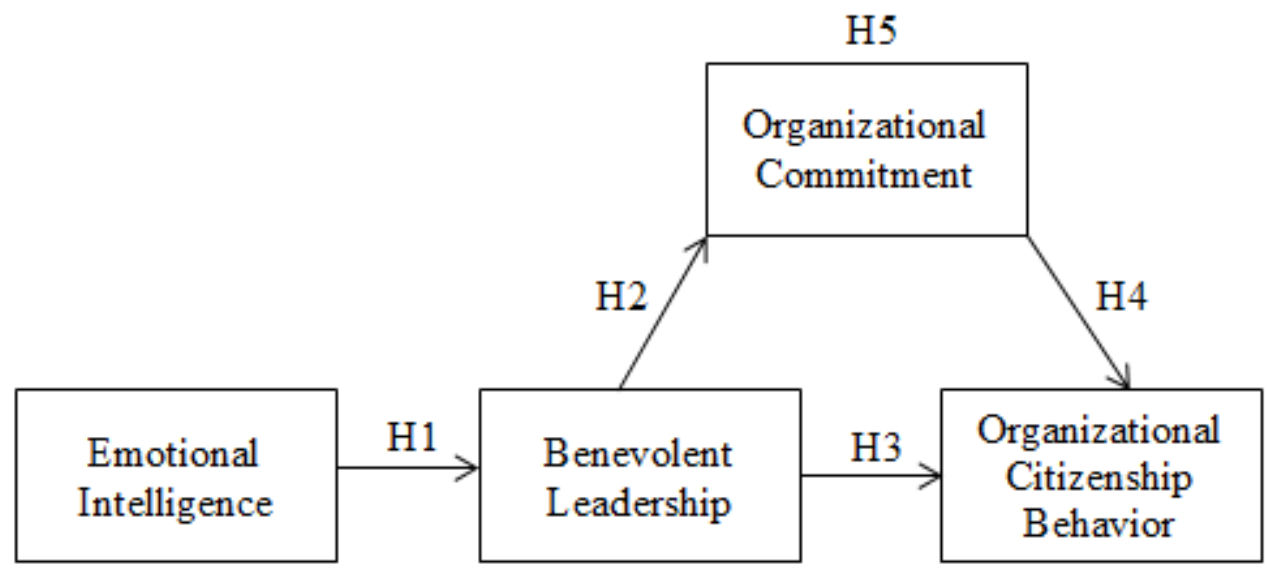

Figure 1: Conceptual Framework

\section{Research Method}

The target population for this study is both employees and their immediate supervisors from various departments in the four- and five-star hotels in Klang Valley of Malaysia. Klang Valley was selected for this study as this region has the highest numbers of four- and five-star hotels in Malaysia (Malaysian Association of Hotels, 2018). A multistage sampling was employed to collect data from the respondents. Firstly, cluster sampling was used to categorize the hotels according to their stars rating. Secondly, judgmental sampling approach was used to select the respondents as 
per the first stage. A total of 300 survey questionnaires were distributed. According to Saunders et al. (2012), a sample size of more than 300 is considered sufficient to represent the population of hotel employees. However, out of the 198 returned questionnaires, only 164 responses were usable. The rest were rejected due to the issue of missing values.

Since the present study addresses the benevolent leadership of the leaders and emotional intelligence of the employees, two groups of respondents were involved in the study, namely the hotel staff and their immediate supervisors. The combination response between the staff and their immediate supervisors was made possible with the assistance from the human resource departments of the hotels involved in this study. The supervisors were required to respond to the measurement items of emotional intelligence and employees were required to rate their leaders' benevolent leadership and their own organizational commitment and organizational citizenship behavior. The questionnaire was pretested through a panel of five experts from the hospitality industry and academics in order to ascertain the face validity of the measurement scales. Moreover, pilot test was conducted before the actual data collection to examine the clarity of the items used in this study. The respondents were given two weeks to complete the questionnaires. The results from the interviews and pilot test found that the survey questions were unambiguous and relevant; hence, the face validity of the measurement scales was established.

As for the context of measurements, this study adopted four measurement instruments, namely, benevolent leadership by Cheng et al. (2004); self-rated emotional intelligence scale by Brackett, Rivers, Shiffman, Lerner, and Salovey (2006); organizational commitment scale by Allen and Meyer (1990) and organizational citizenship behavior by Moorman and Blakely (1995). A total of 73 items were being measured. The sample items for these respective constructs are (1) benevolent leadership: "Beyond work relations, my supervisor expresses concern about my daily life."; (2) emotional intelligence: "By looking at people's facial expressions, I recognize the emotions they are experiencing."; (3) organizational commitment: "I would be very happy to spend the rest of my career with this organization."; and (4) organizational citizenship behaviors: "Voluntarily helps new employees settle into the job". All of the measurement scales were assessed using a 5point Likert scale, ranging from $5=$ strongly agree to $1=$ strongly disagree. The questionnaires employed in this study were made available in two languages, namely English and Bahasa Melayu language.

\section{Results}

\section{Confirmatory Factor Analysis}

Structural equation modeling was used to analyze the data. The fit of the measurement model was examined using maximum likelihood estimation method. The criteria used to evaluate the model fit include Normed Chi-square $\left(\chi^{2} / \mathrm{df}\right)$, Root Mean Square Error of Approximation (RMSEA), Goodness of Fit (GFI), Comparative Fit Index (CFI) and Parsimony Normed Fit Index (PNFI). As suggested by Hair et al. (2010), a model with a good fit would have $\chi^{2} / \mathrm{df}$ of less than 3, RMSEA of less than 0.08, GFI exceeds 0.90, CFI that exceeds 0.90, and a PNFI of more than 0.50 . The results from 
the analysis for all the measures showed a proper fit to the data with $\chi^{2} / \mathrm{df}=1.326$, $\mathrm{RMSEA}=0.038, \mathrm{GFI}=0.893, \mathrm{CFI}=0.930$, and $\mathrm{PNFI}=0.783$.

In order to address the convergent validity, Hair et al. (2010) suggested that there are three criteria that need to be fulfilled, namely (1) the standardized factor loading for each item should be significantly linked to the latent construct with at least a loading estimate of $0.60,(2)$ the construct reliability should be greater than 0.70 and (3) the average variance extracted (AVE) for a construct should be larger than 0.50. A few items from emotional intelligence, organizational commitment and organizational citizenship behavior were dropped from further analysis because the values of its loading were less than the recommended cut-off value of 0.60 . The remaining items satisfied the requirement with a relatively high standardized factor loading values ranged from 0.68 to 0.89 (see Table 1). Moreover, the composite reliability values for all constructs are well above the recommended value of 0.70 . As for the context of AVE, all the constructs in this study have exceeded the minimum standard of 0.50 , which suggests that these constructs explained more than 50 percent of the construct variances.

The discriminant validity of the measurement scales was assessed using the guideline suggested by Fornell and Larcker (1981), where the square root of AVE values should be greater than the correlations between the paired constructs. The results in Table 1 show that the squared root of AVE values of all the constructs are greater than the correlations between paired constructs. In sum, all the measurement constructs included in this study have demonstrated adequate discriminant validity, convergent validity, and reliability.

In addition, the issue of common method variance (CMV) was also addresed in the present study based on the suggestion by Malhotra, Kim, and Patil (2006). According to the past studies, CMV is reported to possibly create a false internal consistency and correlation among the variables resulted from the common source (e.g. Cham, $\mathrm{Ng}$, Lim, \& Cheng, 2018; Chang, van Witteloostuijn, \& Eden 2010; Malhotra et al., 2006). According to Malhotra et al. (2006), CMV exists if the hypothesized model that link the items from all the constructs has a good model fit. As for this study, the results showed that the hypothesized model as suggested above was found not to be fit, which suggested that the common method bias is not a significant problem.

Table 1: Test Results on Convergent Validity, Discriminant Validity, and Reliability

\begin{tabular}{cccccccc}
\hline & C.R & F.L & A.V.E & EI & BL & OC & OCB \\
\hline EI & 0.898 & $0.78-0.89$ & 0.612 & $\mathbf{0 . 7 8 2}$ & & & \\
BL & 0.819 & $0.74-0.87$ & 0.531 & 0.246 & $\mathbf{0 . 7 2 7}$ & & \\
OC & 0.823 & $0.68-0.86$ & 0.592 & 0.173 & 0.286 & $\mathbf{0 . 7 7 5}$ & \\
OCB & 0.856 & $0.69-0.87$ & 0.531 & 0.154 & 0.189 & 0.196 & $\mathbf{0 . 7 3 1}$ \\
\hline
\end{tabular}

Note: EI= Emotional Intelligence, $\mathrm{BL}=$ Benevolent Leadership, OC= Organizational Commitment, $\mathrm{OCB}=$ Organizational Citizenship Behavior, C.R= Composite Reliability, F.L = Factor Loading, A.V.E = Average Variance Extracted. The diagonal entries (in bolds) represent the squared roots average variance, and the off-diagonal entries (in Italics) are the correlations between constructs 


\section{Structural Model and Hypothesis Testing}

The integrated structural model for the present study provides an adequate fit to the data with $\chi 2 / \mathrm{df}=1.219$, RMSEA $=0.035$, GFI $=0.898, \mathrm{CFI}=0.926$, and PNFI $=$ 0.764. Given an adequate measurement model, the hypotheses developed for the present study can be tested by examining the proposed structural model. As for the present study, only hypothesis 1, 2 and hypothesis 4 were supported. Specifically, the results show that emotional intelligence has a direct positive effect on benevolent leadership $(\beta=0.063, \mathrm{p}<0.05)$. Similarly, benevolent leadership was found to have a significant impact on organizational commitment $(\beta=0.734, \mathrm{p}<0.001)$. Moreover, the $\beta=0.866$ and $\mathrm{p}<0.001$ revealed that organizational commitment greatly influences organizational citizenship behavior.

The mediation effect of organizational commitment on the relationship between benevolent leadership and organizational citizenship behavior in the present study was analyzed using the PROCESS macro which developed by Hayes (2013) based in the bootstrapping analysis. The bootstrapping analysis in Table 3 showed that the indirect effect $\beta=0.154$ was significant at 99 confidence level. Also, the $95 \%$ bootstrap confidence interval $(\mathrm{CI})$ does not straddle a 0 in between (lower level $=0.072$, upper level $=0.261$ ) indicates that the mediation effect of organizational commitment is statistically significant (Hayes, 2013).

Table 2: Hypotheses Testing of Structural Model

\begin{tabular}{lccc}
\hline \multicolumn{1}{c}{ Hypothesized Path } & SRW & CR & $\begin{array}{c}\text { Supported } \\
\text { (Yes/No) }\end{array}$ \\
\hline H1: Emotional Intelligence $\rightarrow$ Benevolent Leadership & 0.332 & $2.377^{* * *}$ & Yes \\
H2: Benevolent Leadership $\rightarrow$ Organizational Commitment & 0.734 & $7.113^{* *}$ & Yes \\
H3: Benevolent Leadership $\rightarrow$ OCB & -0.124 & $4.096^{\mathbf{n}}$ & No \\
H4: Organizational Commitment $\rightarrow$ OCB & 0.866 & $4.172^{* *}$ & Yes \\
\hline
\end{tabular}

Note: $\mathrm{CR}=$ critical ratio; $\mathrm{SRW}=$ standardized regression weight, $* * \mathrm{p}$-value $<0.001$, *p-value $<0.05, \mathrm{n}=\mathrm{not}$ significant, $\mathrm{OCB}=$ Organizational Citizenship Behavior

Table 3: Result of Mediation Analysis

\begin{tabular}{|c|c|c|c|c|}
\hline & Indirect & $S E$ & $L L C I$ & ULCI \\
\hline $\mathrm{BL} \rightarrow \mathrm{OC} \rightarrow \mathrm{OCB}$ & 0.154 & 0.036 & 0.072 & 0.261 \\
\hline
\end{tabular}

\section{Discussion and Implications}

Based on the findings above, it is evident that emotional intelligence has significant positive relationship with benevolent leadership. The finding from the present study is consistent with the theory of emotional intelligence whereby it was reported that emotional intelligence is a vital indicator of success in the workplace, especially in leadership and management (Bratton et al., 2011; Goleman, 1995; Pressentin, 2015). This study maintained that the ability of leaders to understand, and manage own and others' emotions is crucial for leaders to express their care for their employees. Hence, the leaders in the management team must not only be able to manage and 
control their own emotions to cope with daily workload and stress, but they also have to be sensitive to others' emotions by engaging social management skills in assisting their employees in achieving personal well-being (Yunus \& Anuar, 2012). The evidence has efficaciously put forward that emotional intelligence plays a critical role in influencing leaders' benevolent leadership ability.

The result of the present study also revealed that there is a positive effect of benevolent leadership towards both organizational commitment and organizational citizenship behaviors. The results are consistent with social exchange theory which proposed that individual's voluntary actions and commitment were motivated from the favorable returns from others (Cropanzano \& Mitchell, 2005). Social exchange theorists implied that employees are willing to exchange their commitment for their leaders' support (Chan \& Mak, 2012; Chen et al., 2018; Eisenberger et al., 1986; Eisenberger et al., 1990; Cropanzano \& Mitchell, 2005). Cropanzano and Mitchell (2005) further stated that leaders' initiative in looking after the employees' well-being might bring positive effect in social exchange relationships, for instances, effective work behavior and positive attitudes among the employees. Employees tend to reciprocate their leaders' kindness by not only being psychologically attached but also contributing to the organization (Chan \& Mak, 2012, Karakas \& Sarigollu, 2012). In other words, organizational citizenship behavior is the outcome of benevolent leadership which is consistent with the findings from the past studies (e.g. Ghosh, 2015; Tang \& Naumann, 2015). The well-treated employees show their gratitude by exercising organizational citizenship behaviors with a sense of obligation (Tang \& Naumann, 2015; Zellars \& Tepper, 2003).

In addition to the above, organizational commitment was also tested as a mediator of the relationship between benevolent leadership and organizational citizenship behavior in the present study. The result shows that organizational commitment was found to have a mediation effect on the relationship between benevolent leadership and organizational citizenship behaviors. This finding put forward that benevolent leadership would enhance the psychological attachment of employees that come from their organizational commitment before the leadership behaviors can influence the employees to be willing to go the extra miles. The support given by the superiors will be able to instill commitment among their employees and promote togetherness among them in which could enhance the business processes and its performance. Moreover, this initiative allows the employees to contribute beyond managerial expectation, while promoting the company that they attached to outsider for imagebuilding purpose and remained loyal to the company.

As for the context of practical implications, this study suggests that the management of the hotel industry should focus particularly on enhancing their human resource development and human resource management initiatives and practices. Firstly, the improvement of human resource policies should be considered with the objective to identify, stimulate, advocate and aspire benevolent behavior among potential leaders. The benevolent characteristics of candidates can be identified in the process of recruitment and selection via aptitude or personality test. By hiring potential candidates who have already possessed benevolent leaders' characteristics, the company incurs lesser cost in training and shaping the desired leadership style. Secondly, the organization can devise effective training programs that equip the leaders with the components of benevolent leadership behavior. The components of 
its antecedent, for instance, emotional intelligence, can also be integrated into the training content to allow improvement in benevolent practices. Thirdly, the performance appraisal and reward system should be enhanced in order to reinforce the benevolent behavior among the employees, particularly those with leadership responsibilities. A well-structured appraisal process and equitable rewards prompt individuals to repeat the desired behavior.

\section{Limitations, Further Research Directions and Conclusion}

There are several limitations in this study from a scientific perspective. Firstly, the measurement instrument of benevolent leadership was derived from the questionnaire of paternalistic leadership. To date, there is no instrument of benevolent leadership, which was solely developed for benevolent leadership itself and can be evaluated by third party. The current version of measuring instruments is either self-rated by leaders (e.g. Karakas \& Sarigollu, 2012) or it is one of the dimensions from other measuring instrument (e.g. Cheng et al., 2004). Although Cheng et al.'s (2004) instrument has been widely used in benevolent leadership studies; there is still a need to constitute an independent and employee-rated measuring instrument to enhance the validity of the construct. Secondly, this study adopted the survey method for data collection due to time and cost constraints. Common errors of survey method such as social desirability bias, acquiescence bias and confusion bias are unavoidable. Hence, the increasingly popular qualitative research or mixed methods can be conducted to better explore the antecedents and outcomes of benevolent leadership. By interviewing respondents, richer information can be collected and deeper understanding of human behaviors can be obtained.

The other limitation is that this study only proposed one antecedent of benevolent leadership. This area is worth investigating as the exploration of antecedents allows researchers to better identify the potential traits and requirements of a benevolent leader. However, there are still perceptibly limited studies which propose the factors that contribute to benevolent behavior. Future studies are needed to examine other organizational factors such as the leader's traits, self-efficacy, locus of control and integrity as the antecedents of benevolent leadership to further strengthen the construct. Lastly, this study was conducted in Klang Valley (Selangor, Kuala Lumpur and Putrajaya), Malaysia. As a multicultural context, Malaysia provides diverse samples that enhance the generalizability of this study. Yet, this study only focused on the hotel industry in Malaysia. A comparison may be observed in future studies between public and private sectors, manufacturing and service industries, multinationals and small-and-medium corporations, or companies in urban and rural areas.

As a conclusion, it is evident that there is still a room for more research to be conducted in the context of benevolent leadership. The present study successfully extended the body of knowledge by focusing on the antecedent of benevolent leadership that is still immensely scarce in the past literature. Moreover, this is also one of the first studies that found emotional intelligence as a predictor of benevolent leadership and the organizational commitment fully mediated the relationship between benevolent leadership and organizational citizenship. With the growth of the tourism industry in Malaysia, the hotel industry represents a great business 
opportunity for international and local hoteliers. Hence, it is important for the hotel players in Malaysia to grasp and understand the importance of emotional intelligence and benevolent leadership in the hope to reduce employee turnover. This initiative is expected to assist the hotels in promoting conducive and supportive working environment for the staff, which is critical in creating a sustainable environment for the career aspirants in the hotel industry.

\section{References}

Abdullah, R. B., Alias, M. A. M., Zahari, H., Karim, N. A., Abdullah, S. N., Salleh, H., \& Musa, M. F., (2010), The study of factors contributing to chef turnover in hotels in Klang Valley, Malaysia, Asian Social Science, vol. 6, no. 1, pp. 80-85.

Ahmadi, F., \& Avajian, Z., (2011), Survey relationship between organizational citizenship and organizational commitment in public organization in Iran, Interdisciplinary Journal of Contemporary Research In Business, vol. 3, no. 5, pp. 381-394.

Ahmed, I., Mohammad, S. K., \& Islam, T., (2013), The relationship between perceived fairness in performance appraisal and organizational citizenship behavior in the banking sector of Pakistan: The mediating role of organizational commitment, International Journal of Management \& Innovation, vol. 5, no. 2, pp. 75-88.

Ahuja, K. K., Padhy, P., \& Srivastava, G., (2018), Performance appraisal satisfaction \& organizational commitment, Indian Journal of Industrial Relations, vol. 53, no. 4, pp. 675-692.

Albattat, A. R. S., \& Som, A. P. M., (2013), Employee dissatisfaction and turnover crises in the Malaysian hospitality industry, International Journal of Business and Management, vol. 8, no. 5, pp. 62.

Al-sharafi, H., \& Rajiani, I., (2013), Leadership practices and talent turnover: Study on Yemeni organizations, Business and Management Research, vol. 2, no. 3, pp. 60-67.

Allen, N. J., \& Meyer, J. P., (1990), Organizational socialization tactics: A longitudinal analysis of links to newcomers' commitment and role orientation, Academy of Management Journal, vol. 33, no.4, pp. 847-858.

Allen, N. J., \& Meyer, J. P., (2000), Construct validation in organizational behavior research: The case of organizational commitment, In Goffin, R. D., Helmes, E., Problems and solutions in human assessment: Honouring Douglas N. Jackson at seventy, Kluwer, pp. 285-314.

Ayupp, K., \& Kong, W., (2010), The impact of task and outcome interdependence and selfefficacy on employees' work motivation: An analysis of the Malaysian retail industry, Asia Pacific Business Review, vol. 16, no. 1-2, pp. 123-142.

Bar-On, R., (2006), The Bar-On Model of Emotional-Social Intelligence (ESI), Psicothema, 18 Supp 113-25.

Bateman, T. S., \& Strasser, S., (1984), A longitudinal analysis of the antecedents of organizational commitment, Academy of Management Journal, vol. 27, no. 1, pp. 95112.

Bateman, T. S., \& Organ, D. W., (1983), Job satisfaction and the good soldier: The relationship between affect and employee "citizenship", Academy of Management Journal, vol. 26, no. 4, pp. 587-595.

Behery, M., Al-Nasser, A. D., Jabeen, F., \& El Rawas, A. S., (2018), Toxic Leadership and organizational citizenship behavior: A mediation effect of followers' trust and commitment in the Middle East, International Journal of Business \& Society, vol. 19, no. 3, pp. 793-815.

Brackett, M. A., Rivers, S. E., Shiffman, S., Lerner, N., \& Salovey, P., (2006), Relating emotional abilities to social functioning: A comparison of self-report and performance measures of emotional intelligence, Journal of Personality and Social Psychology, vol. 91, no. 4, pp. 780 . 
Bratton, V. K., Dodd, N. G., \& Brown, F. W., (2011), The impact of emotional intelligence on accuracy of self-awareness and leadership performance, Leadership \& Organization Development Journal, vol. 32, no. 2, pp. 127-149.

Caillier, J. G., (2015), Transformational leadership and whistle-blowing attitudes: Is this relationship mediated by organizational commitment and public service motivation?, The American Review of Public Administration, vol. 45, no. 4, pp. 458475.

Cham, T. H., \& Easvaralingam, Y., (2012), Service quality, image and loyalty towards Malaysian hotels, International Journal of Services, Economics and Management, vol. 4, no. 4, pp. 267-281.

Cham, T. H., Ng, C. K. Y., Lim, Y. M., \& Cheng, B. L., (2018), Factors influencing clothing interest and purchase intention: A study of Generation Y consumers in Malaysia, The International Review of Retail, Distribution and Consumer Research, vol. 28, no. 2, pp. 174-189.

Chan, S. C., (2017), Benevolent leadership, perceived supervisory support, and subordinates' performance: The moderating role of psychological empowerment, Leadership \& Organization Development Journal, vol. 38, no. 7, pp. 897-911.

Chan, S. C., \& Mak, W. M., (2012), Benevolent leadership and follower performance: The mediating role of leader-member exchange (LMX), Asia Pacific Journal of Management, vol. 29, no. 2, pp. 285-301.

Chang, S. J., Van Witteloostuijn, A., \& Eden, L., (2010), From the editors: Common method variance in international business research, Journal of International Business Studies, vol. 41 , no. 2 , pp. $178-184$.

Chen, X. P., Eberly, M. B., Chiang, T. J., Farh, J. L., \& Cheng, B. S., (2014), Affective trust in Chinese leaders: Linking paternalistic leadership to employee performance, Journal of Management, vol. 40, no. 3, pp. 796-819.

Chen, T. J., \& Wu, C. M., (2017), Improving the turnover intention of tourist hotel employees: Transformational leadership, leader-member exchange, and psychological contract breach, International Journal of Contemporary Hospitality Management, vol. 29, no. 7, pp. 1914-1936.

Chen, Y., Zhou, X., \& Klyver, K., (2018), Collective efficacy: Linking paternalistic leadership to organizational commitment, Journal of Business Ethics, pp. 1-17, doi: https://doi.org/10.1007/s10551-018-3847-9

Cheng, B. L., Mansori, S., \& Cham, T. H., (2014), The associations between service quality, corporate image, customer satisfaction, and loyalty: Evidence from the Malaysian hotel industry, Journal of Hospitality Marketing \& Management, vol. 23, no. 3, pp. 314-326.

Cheng, B. S., Chou, L. F., Wu, T. Y., Huang, M. P., \& Farh, J. L., (2004), Paternalistic leadership and subordinate responses: Establishing a leadership model in Chinese organizations, Asian Journal of Social Psychology, vol. 7, no. 1, pp. 89-117.

Chu, P. C., \& Hung, C. C., (2009), The relationship of paternalistic leadership and organizational citizenship behavior: The mediating effect of upward communication, Journal of Human Resource and Adult Learning, vol. 5, no. 2, pp. 6673.

Cook, C. R., (2006), "Effects of emotional intelligence on principals' leadership performance" (Doctoral Dissertation), Retrieved from http://scholarworks.montana .edu/xmlui /bitstream/handle /1/1099/cookc0506.pdf?sequence $=1$

Cropanzano, R., \& Mitchell, M. S., (2005), Social exchange theory: An interdisciplinary review, Journal of Management, vol. 31, no. 6, pp. 874-900.

Dabke, D., (2016), Impact of leader's emotional intelligence and transformational behavior on perceived leadership effectiveness: A multiple source view, Business Perspectives and Research, vol. 4, no.1, pp. 27-40.

Desrosiers, M. E., \& Thomson, S., (2011), Rhetorical legacies of leadership: Projections of 'benevolent leadership' in pre-and post-genocide Rwanda, The Journal of Modern African Studies, vol. 49, no. 3, pp. 429-453. 
Dhar, R. L., (2015), Service quality and the training of employees: The mediating role of organizational commitment, Tourism Management, vol. 46, pp. 419-430.

Eisenberger, R., Huntington, R., Hutchison, S., \& Sowa, D., (1986), Perceived organizational support, Journal of Applied psychology, vol. 71, no. 3, pp. 500-507.

Eisenberger, R., Fasolo, P., \& Davis-LaMastro, V., (1990), Perceived organizational support and employee diligence, commitment, and innovation, Journal of Applied Psychology, vol. 75, no. 1, pp. 51-59.

Erben, G., \& Güneşer, A. (2008), The relationship between paternalistic leadership and organizational commitment: Investigating the role of climate regarding ethics, Journal of Business Ethics, vol. 82, no. 4, pp. 955-968.

Erkutlu, H., \& Chafra, J., (2016), Benevolent leadership and psychological well-being: The moderating effects of psychological safety and psychological contract breac, Leadership \& Organization Development Journal, vol. 37, no. 3, pp. 369-386.

Farh, J. L., \& Cheng, B. S., (2000), A cultural analysis of paternalistic leadership in chinese organizations, In Li, T. J., Tsui, A. S., \& Weldon, E., Management and organizations in the Chinese context, Macmillan, pp. 85-127.

Farh, J. L., Cheng, B. S., Chou, L. F., \& Chu, X. P., (2006), Authority and benevolence: Employees' responses to paternalistic leadership in China, Tsui, A. S., Bian, Y., \& Cheng, L., China's domestic private firms: Multidisciplinary perspectives on management and performance, Sharpe, pp. 230-260.

Ferreira, A. I., Martinez, L. F., Lamelas, J. P., \& Rodrigues, R. I., (2017), Mediation of job embeddedness and satisfaction in the relationship between task characteristics and turnover, International Journal of Contemporary Hospitality Management, vol. 29, no. 1, pp. 248-267.

Fornell, C., \& Larcker, D. F., (1981), Structural equation models with unobservable variables and measurement error: Algebra and statistics, Journal of Marketing Research, vol. 18, no. 3, pp. 382-388.

Gardner, H., (1983), Frames of mind, Basic Books.

Ghosh, K., (2015), Benevolent leadership in not-for-profit organizations: Welfare orientation measures, ethical climate and organizational citizenship behavior, Leadership \& Organization Development Journal, vol. 36, no.5, pp. 592-611.

Goleman, D. P., (1995), Emotional intelligence: Why it can matter more than IQ for character, health and lifelong achievement, New York: Bantam Books.

Gumusluoglu, L., Karakitapoğlu-Aygün, Z., \& Scandura, T. A., (2017), A multilevel examination of benevolent leadership and innovative behavior in $R \& D$ contexts: A social identity approach, Journal of Leadership \& Organizational Studies, vol. 24, no. 4, pp. 479-493.

Gunzler, D., Chen, T., Wu, P., \& Zhang, H., (2013), Introduction to mediation analysis with structural equation modeling, Shanghai Archives of Psychiatry, vol. 25, no. 6, pp. 390.

Hair, J. F. J., Black, W. C., Babin, B. J., Anderson, R. E., \& Tatham, R. L., (2010), Multivariate data analysis a global perspective, Pearson Education International.

Han, S. H., Seo, G., Yoon, S. W., \& Yoon, D. Y., (2016), Transformational leadership and knowledge sharing: Mediating roles of employee's empowerment, commitment, and citizenship behaviors, Journal of Workplace Learning, vol. 28, no. 3, pp. 130-149.

Hayes, A. F. (2013), "Introduction to mediation, moderation, and conditional process analysis", Retrieved from http://www.personal.psu.edu/jxb14 /M554/specreg/templa tes.pdf

Hong, Y., Catano, V. M., \& Liao, H., (2011), Leader emergence: The role of emotional intelligence and motivation to lead, Leadership \& Organization Development Journal, vol. 32, no. 4, pp. 320-343.

Huang, S. S., Veen, R. V., \& Song, Z. C., (2018), The impact of coping strategies on occupational stress and turnover intentions among hotel employees, Journal of Hospitality Marketing \& Management, vol. 27, no. 8, pp. 1-20.

Karakas, F., \& Sarigollu, E., (2012), Benevolent leadership: Conceptualization and construct development, Journal of Business Ethics, vol. 108, no. 4, pp. 537-553. 
Kelly Services, (2012), "The leadership disconnect”, Retrieved from: http://www.kellyocg.com/uploadedFiles/Content/Knowledge/Kelly_Global_Workforce _Index_Content/The\%20Leadership\%20 Disconnect.pdf

Khan, S. K., \& Rashid, M. Z. A., (2012), The mediating effect of organizational commitment in the organizational culture, leadership and organizational justice relationship with organizational citizenship behavior: A study of academicians in private higher learning institutions in Malaysia, International Journal of Business and Social Science, vol. 3, no. 8, pp. 83-91.

Kim, H., (2014), Transformational leadership, organizational clan culture, organizational affective commitment, and organizational citizenship behavior: A case of South Korea's public sector, Public Organization Review, vol. 14, no. 3, pp. 397-417.

Lee, J. J., \& Ok, C., (2012), Reducing burnout and enhancing job satisfaction: Critical role of hotel employees' emotional intelligence and emotional labor, International Journal of Hospitality Management, vol. 31, no. 4, pp. 1101-1112.

Li, G., Rubenstein, A. L., Lin, W., Wang, M., \& Chen, X., (2018), The curvilinear effect of benevolent leadership on team performance: The mediating role of team action processes and the moderating role of team commitment, Personnel Psychology, vol. 71, no. 3, pp. 369-397.

Lin, W., Ma, J., Zhang, Q., Li, J. C., \& Jiang, F., (2016), How is benevolent leadership linked to employee creativity? The mediating role of leader-member exchange and the moderating role of power distance orientation, Journal of Business Ethics, vol. 152, no. 4, pp. 1099-1115.

Lindebaum, D., \& Cartwright, S., (2011), Leadership effectiveness: The costs and benefits of being emotionally intelligent, Leadership \& Organization Development Journal, vol. 32, no. 3, pp. 281-290.

Lo, K., \& Lamm, F., (2005), Occupational stress in the hospitality industry - An employment relations perspective, New Zealand Journal of Employment Relations, vol. 30, no. 1, pp. 23-47.

MacKenzie, S. B., Podsakoff, P. M., \& Ahearne, M., (1998), Some possible antecedents and consequences of in-role and extra-role salesperson performance, Journal of Marketing, vol. 62 , no. 3, pp. 87-98.

Malaysian Association of Hotels, (2018), "Hotel directories", Retrieved from http://www.ho tels.or g.my/directories.html

Mastura, J., Toh, K. I., \& Zaleha, S. M. S., (2011), Problems of small and medium budget hotel operators, World Applied Sciences Journal 12 (Special Issue of Tourism \& Hospitality), pp. 73-79.

McEnrue, P. M., Groves, K. S., \& Shen, W., (2009), Emotional intelligence development: Leveraging individual characteristics, Journal of Management Development, vol. 28, no. 2, pp. 150-174.

Malhotra, N. K., Kim, S. S., \& Patil, A., (2006), Common method variance in IS research: A comparison of alternative approaches and a reanalysis of past research, Management science, vol. 52, no. 12, pp. 1865-1883.

Mayer, R. C., \& Schoorman, F. D., (1998), Differentiating antecedents of organizational commitment: A test of March and Simon's model, Journal of Organizational Behavior: The International Journal of Industrial, Occupational and Organizational Psychology and Behavior, vol. 19, no. 1, pp. 15-28.

Ministry of Human Resource Malaysia, (2017a), "Kekosongan mengikut negeri dan industri Januari 2017", Retrieved from: http://www.data.gov.my/data/ms_MY/ dataset/kekos ongan-mengikut-negeri-dan-industri-januari-2017/resource/ 0a00bde5-cd75-429a-9318$23 \mathrm{f} 6 \mathrm{a} 8 \mathrm{dd} 6 \mathrm{a} 54$

Ministry of Human Resource Malaysia, (2017b), "Kekosongan mengikut negeri dan industri Disember 2017", Retrieved from: http://www.data.gov.my/data/ms_MY/ dataset/keko songan-mengikut-negeri-dan-industri-disember-2017/resource/013abdf8-afbd-4c87-a0b 6-e81d261d1263 
Moore, K. R., \& Cunningham, W. A., (1999), Social exchange behavior in logistics relationships: A shipper perspective, International Journal of Physical Distribution \& Logistics Management, vol. 29, no. 2, pp.103-121.

Moorman, R. H., \& Blakely, G. L., (1995), Individualism-collectivism as an individual difference predictor of organizational citizenship behavior, Journal of Organizational Behavior, vol. 16, no. 2, pp. 127-142.

Mowday, R. T., Steers, R. M., \& Porter, L. W., (1979), The measurement of organizational commitment, Journal of Vocational Behavior, vol. 14, no. 2, pp. 224-247.

Nankervis, A., Compton, R., \& Baird, M., (2008), Human resource management: Strategies and processes, Thomson.

Neubert, M. J., Wu, C., \& Roberts, J. A., (2013), The influence of ethical leadership and regulatory focus on employee outcomes, Business Ethics Quarterly, vol. 23, no. 2, pp. 269-296.

Niu, C. P., Wang, A. C., \& Cheng, B. S., (2009), Effectiveness of a moral and benevolent leader: Probing the interactions of the dimensions of paternalistic leadership, Asian Journal of Social Psychology, vol. 12, no. 1, pp. 32-39.

Othman, J., Abdullahi Mohammed, K., \& Lawrence, D. S. J., (2013), Does a transformational and transactional leadership style predict organizational commitment among public university lecturers in Nigeria?, Asian Social Science, vol. 9, no. 1, pp. 165-170.

Organ, D. W, (1990), The motivational basis of organizational citizenship behavior, Research in Organizational Behavior, vol. 12, no. 1, pp. 43-72.

Organ, D. W., \& Ryan, K., (1995), A meta-analytic review of attitudinal and dispositional predictors of organizational citizenship behavior, Personnel Psychology, vol. 48, no. 4, pp. 775-802.

Peterson, D. K., \& Xing, Y., (2007), Correlates and predictors to organizational commitment in China, Journal of Asia Business Studies, vol. 1, no. 2, pp. 27-36.

Podsakoff, P. M., MacKenzie, S. B., (1997), Impact of organizational citizenship behavior on organizational performance: A review and suggestion for future research, Human Performance, vol. 10, no. 2, pp. 133-151.

Podsakoff, P. M., MacKenzie, S. B., Paine, J. B., \& Bachrach, D. G., (2000), Organizational citizenship behaviors: A critical review of the theoretical and empirical literature and suggestions for future research, Journal of Management, vol. 26, no. 3, pp. 513-563.

Polychroniou, P. V., (2009), Relationship between emotional intelligence and transformational leadership of supervisors: The impact on team effectiveness, Team Performance Management: An International Journal, vol. 15, no. 7/8, pp. 343-356.

Pressentin, M., (2015), Universal leadership approaches \& cultural dimensions: The expression of Asian leadership traits, Amity Global Business Review, vol. 10, pp. 19-38.

Riketta, M., \& Landerer, A., (2002), Organizational commitment, accountability, and work behavior: A correlational study, Social Behavior and Personality: An international journal, vol. 30, no. 7, pp. 653-660.

Rosnani, T., (2018), Trust in leadership and affective commitment as a mediator between servant leadership behavior and extra-role behavior of teachers, Journal of Management \& Marketing Review, vol. 3, no. 3, pp. 149-155.

Rowden, R. W., (2000), The relationship between charismatic leadership behaviors and organizational commitment, Leadership \& Organization Development Journal, vol. 21, no. 1, pp. 30-35.

Saad, S., Yahya, K. K., \& Pangil, F., (2012), Integrated business strategy and its constructs: Pilot study at hotels in Malaysia, Journal of Global Management, vol. 3, no. 1, pp. 3442.

Salovey, P., \& Mayer, J. D., (1990), Emotional intelligence, Imagination, Cognition and Personality, vol. 9, no. 3, pp. 185-211.

Salman, A., \& Hasim, M. S., (2012), Factors and competitiveness of Malaysia as a tourist destination: A study of outbound Middle East tourists, Asian Social Science, vol. 8, no. 12, pp. 48. 
Sangaran, G., \& Jeetesh, K., (2015), The effects of job satisfaction towards employee turnover in the hotel industry: A case study of hotels in Kuala Lumpur City Center, Journal of Tourism and Hospitality, vol. 4, no. 142, pp. 2167-0269.

Saunders, M., Lewis, P., \& Thornhill A., (2012), Research methods for business students, Pearson.

Smollan, R., \& Parry, K., (2011), Follower perceptions of the emotional intelligence of change leaders: A qualitative study, Leadership, vol. 7, no. 4, pp. 435-462.

Stein, S. J., Papadogiannis, P., Yip, J. A., \& Sitarenios, G., (2009), Emotional intelligence of leaders: A profile of top executives, Leadership \& Organization Development Journal, vol. 30, no. 1, pp. 87-101.

Suliman, A. M., (2001), Work performance: is it one thing or many things? The multidimensionality of performance in a Middle Eastern context, International Journal of Human Resource Management, vol. 12, no.6, pp. 1049-1061.

Sušanj, Z., \& Jakopec, A., (2012), Fairness perceptions and job satisfaction as mediators of the relationship between leadership style and organizational commitment, Psihologijske teme, vol. 21, no. 3, pp. 509-526.

Tang, C., \& Naumann, S. E., (2015), Paternalistic leadership, subordinate perceived leadermember exchange and organizational citizenship behavior, Journal of Management \& Organization, vol. 21, no. 3, pp. 291-306.

Wang, A., \& Cheng, B., (2010), When does benevolent leadership lead to creativity? The moderating role of creative role identity and job autonomy, Journal of Organizational Behavior, vol. 31, no. 1, pp. 106-121.

Wong, C. S., \& Law, K. S., (2002), The effects of leader and follower emotional intelligence on performance and attitude: An exploratory study, The Leadership Quarterly, vol. 13, no. 3 , pp. 243-274.

World Travel and Tourism Council, (2017), "Travel and tourism economic impact 2017 Malaysia", Retrieved from https://www.wttc.org/-/media/files/reports/economic-impact -research/countries-2017/malaysia2017.pdf

Youn, H. W., Kim, J. H., \& Song, H. Q., (2017), The leading causes and consequences of citizenship pressure in the hotel industry, International Journal of Contemporary Hospitality Management, vol. 29, no. 6, pp. 1541-1559.

Yousef, D. A., (2017), Organizational commitment, job satisfaction and attitudes toward organizational change: A study in the local government, International Journal of Public Administration, vol. 40, no. 1, pp. 77-88.

Yunus, N. H. P., \& Anuar, S. R., (2012), Trust as moderating effect between emotional intelligence and transformational leadership styles, Interdisciplinary Journal of Contemporary Research in Business, vol. 3, no. 10, pp. 650-663.

Zellars, K. L., \& Tepper, B. J., (2003), Beyond social exchange: New directions for organizational citizenship behavior theory and research, In Research in personnel and human resources management, Emerald Group Publishing Limited, pp. 395-424. 